\title{
UPAYA KEPALA MADRASAH DALAM MENINGKATKAN KINERJA GURU DI MADRASAH TARBIYAH ISLAMIYAH JAHO
}

\author{
Yunelda \\ Pengawas Madrasah, Kementerian Agama Kabupaten Tanah Datar \\ Jl. Cubadak Limo Kaum, Supanjang, Batusangkar Sumatera Barat \\ e-mail: yuneldaummikalsum@gmail.com
}

\begin{abstract}
The purpose of this study to determine the headmaster efforts in improving the performance of teachers in the madrasas tarbiyah islamiyah jaho. This study user a qualitative method using fenomologi perspective. Data collection techniques such as observation, interviews adn documentation study. Subjec this study headmaster, administration and teacher of Madrasas Tarbiyah Islamiyah Jaho. As for test data by tringulasi, tchniques of data analysis with qualitative descriptive analysis. As for the result of this study Were (1) the efforts headmaster ini improving the performance of teacher in the field of lessin plans that inculde teacher Training or Training event and Activities MGMP. (2) efforts headmaster in improving teacher performance in the implementation of learning is that the Monitoring and Supervision with Supervision. (3) attempts headmaster in improving teacher performance evaluation in the field of learning that check book value of teacher and teacher analysis of Daily tests.
\end{abstract}

Keywords: efforts, head master, teacer performance

\section{PENDAHULUAN}

Kinerja sebagai tingkat pelaksanaan tugas yang dapat di capai seseorang dengan menggunakan kemampuan yang ada dan batasan-batasan yang telah di tetapkan untuk mencapai tujuan organisasi. kinerja juga merupakan prestasi yang dicapai oleh seseorang dalam melaksanakan tugasnya atau pekerjaannya selama periode tertentu sesuai standar dan kriteria yang telah di tetapkan untuk pekerjaan tersebut.

Dalam proses pendidikan di sekolah, guru adalah salah satu unsur pelaksana pendidikan yang memegang peranan penting yakni sebagai educator, fasilitator, dan motivator. Guru adalah seorang yang mengabdi atau memberikan ilmu pengetahuan kepada peserta didiknya. Dalam arti luas dapat diungkapkan bahwa guru adalah seorang yang melaksanakan tugas di lembaga pendidik, di mana masyarakat percaya kepadanya untuk melakukan tugas yang dipercayakan kepada dalam rangka mencerdaskan peserta didik.

Masalah kinerja bagi guru adalah masalah yang sangat penting. Tanpa adanya kinerja yang baik tidak mungkin madrasah dapat menghasilkan peserta didik yang kompetitif.

Peningkatan kinerja mempunyai implikasi yang positif bagi madrasah itu sendiri, artinya madrasah dapat menghasilkan kuantitas dan kualitas peserta didik yang 
optimal. Kinerja guru akan meningkat bila didukung oleh penerapan sistem manajemen kinerja dan sistem pengembangan karir yang baik dan efektif. Bila system manajemen kerja sudah meningkat secara otomatis mutu pendidikan di madrasah tersebut juga akan meningkat.

Untuk memiliki kinerja yang baik guru hendaknya memiliki beberapa kompetensi yang akan digunakan dalam melaksanakan tugasnya sebagai seorang pendidik. Berdasarkan peraturan menteri pendidikan nasional republik Indonesia nomor 16 tahun 2007 tentang standar kualifikasi akademik dan kompetensi guru dijelaskan bahwa standar kompetensi guru dikembangkan secara utuh dari 4 kompetensi utama yaitu: (1) kompetensi pedagogik, (2) kepribadian, (3) sosial, dan (4) profesional. Keempat kompetensi tersebut terintegrasi dalam kinerja guru. (Jamaan Satorik, 2008)

Menurut Yurman (2008) ada tiga tugas utama guru dan tanggung jawab seorang guru, yaitu guru sebagai pengajar, guru sebagai pembimbing, dan guru sebagai administrator dalam kelas. Sebagai pengajar guru di tuntut memiliki kemampuan dalam tugasnya mulai dari kegiatan merencanakan, dan melaksanakan proses pembelajaran hingga proses evaluasi. Guru sebagai pembimbing dan pendidik harus memiliki kecakapan atau kemampuan apalagi pada usaha memberikan bantuan serta solusi permasalahan yang dihadapi oleh peserta didik. Sedangkan guru sebagai administrator, guru harus memiliki kemampuan dalam ketatalaksanaan bidang pelajaran.

Menurut Pandji (2007) Berbicara kinerja guru adalah hasil karya yang di capai oleh seseorang dalam melaksanakan tugas yang di berbebankan kepadanya, hal ini tentu di dorong oleh kekuatan seseorang untuk melakukan pekerjaan. Dalam psikologi kerja, kinerja disebut sebagai hasil yang di capai seseorang yang didorong semangat kerja. Seseorang akan memiliki kemauan kerja yang tinggi apabila kebutuhannya terpenuhi baik kebutuhan lahir maupun kebutuhan batin. Dengan tingginya semangat kerja seseorang akan berusaha melakukan pekerjaan secara maksimal. Dengan semangat kerja yang tinggi para guru akan terdorong untuk bekerja semaksimal mungkin dalam melaksanakan tugasnya. Dalam kenyataannya para guru tidak selalu bekerja dengan kinerja yang tinggi, di kalangan guru Madrasah Tarbiyah Islamiyah Jaho.

Pada Kecamatan X Koto terdapat beberapa Madrasah, yaitu terdapat 1 Madrasah negeri dan beberapa Madrasah swasta. Madrasah Tarbiyah Islamiyah Jaho salah satu Madrasah swasta yang ada di Kecamatan X Koto, tepatnya di daerah Jaho. Pada Madrasah Tarbiyah Islamiyah Jaho terdapat 20 orang guru dan siswa 70 orang. Kemudian di Madrasah Tarbiyah Islamiyah Jaho juga terdapat 4 guru yang berstatus Pegawai Negeri Sipil dan selainya guru yang mengajar di sana adalah guru honor juga guru sertifikasi menambah jam. Secara tanggung jawab dan guru yang berstatus pegawai yang tetap tentu memiliki tanggung jawab dan beban yang berbeda. Selain itu di Madrasah Tarbiyah Islamiyah Jaho juga belum memadainya kualitas dan relevansi pendidikan, rendahnya anggaran pendidikan pemerintah, manajemen pendidikan yang masih sentralistik ternyata telah membawa permasalahan dasar di

\section{4


bidang pendidikan termasuk kinerja guru yang menjadi fokus penelitian ini.

Dari pengamatan awal yang penulis lakukan di Madrarsah Tarbiyah Islamiyah (MTI) Syekh Muhammad Djamil Jaho, ditemukan beberapa permasalahan yaitu dari segi kedisiplinan masih ada guru yang masuk terlambat dan cepat pulang atau urusan pribadi di jam mengajar, dan dari segi kualifikasi serta tugas mengajar masih ada guru yang belum S1 dan memang terlihat suasana berbeda jika di bandingkan dengan yang penulis temukan di madrasah lain, perbedaan ini terutama pada sikap dan karakter gurunya, di antaranya:

1. Sebagian guru yang mengajar di Madrasah Tarbiyah Islamiyah (MTI) Syekh Muhammad Djamil Jaho ini berstatus sebagai guru honor

2. Sebagian guru tamatan SLTA (lulusan MTI Jaho)

3. Pada bidang kurikulum Madrasah Tarbiyah Islamiyah (MTI) Jaho terlalu banyak mata pelajaran.

4. Banyaknya guru yang hanya berada pada sekolah pada jam pelajaran saja dan jarang mengisi daftar hadir

5. Tidak adanya rekapan absen kehadiran guru tiap bulannya

6. Tenaga administrasi tidak bekerja tidak maksimal

7. Pada bidang sarana dan prasarana masih banyak kekurangan sarana pendukung di antaranya belum adanya tempat ibadah, dan buku-buku pelajaran masih kurang.

8. Kepala madrasah yang secara kompetensi tidak berasal dari bidang pendidikan

9. Rendahnya semangat bekerja bagi guru seperti tidak membuat persiapan mengajar
10. Kurangnya kegigihan para guru untuk mendorong keberhasilan belajar siswa

11. Guru hanya sebagian yang membuat persiapan mengajar yaitu guru yang sertifikasi saja

12. Hasil belajar siswa kurang memuaskan hanya syarat untuk lulus

13. Masih minimnya usaha guru untuk meningkatkan kompetensi diri. (wawancara dengan TU)

Dari sekian banyak permasalahan mengenai pendidikan di Madrasah Tarbiyah Islamiyah Jaho maka penulis memfokuskan penelitian ini pada Upaya kepala madrasah dalam meningkatkan kinerja guru di Madrasah Tarbiyah Islamiyah Jaho. Adapun tujuan dari penelitian ini adalah upaya kepala madrasah dalam meningkatkan kinerja guru pada rencana pembelajaran di Madrasah Tarbiyah Islamiyah Jaho, upaya kepala madrasah dalam meningkatkan kinerja guru pada proses pelaksanaan pembelajaran di Madrasah Tarbiyah Islamiyah Jaho serta upaya kepala madrasah dalam meningkatkan kinerja guru pada evaluasi atau penilaian pembelajaran di Madrasah Tarbiyah Islamiyah Jaho dan upaya kepala madrasah dalam meningkatkan kinerja guru di bidang disiplin guru pada Madrasah Tarbiyah Islamiyah Jaho.

\section{KOMPEIENSI KEPALAMADRASAH}

Menurut Emali, "kepemimpinan kepala madrasah merupakan salah satu aspek manajerial dalam organisasi dan berperan sebagai penyelaras dalam proses kerja sama antara dan dalam organisasi, dalam hal itu kepala sekolah berupaya memberdayakan sumber daya sekolah dalam mengelola sekolah yang dipimpin 
untuk mencapai tujuan-tujuan yang telah ditetapkan. (Gouzali, 2000)

Kepala madrasah di samping mempunyai kemampuan kepemimpinan juga mempunyai ciri-ciri kepemimpinan yang berprinsip. Menurut "Iddocho kepala madrasah menduduki dua jabatan penting yaitu: kepala madrasah adalah pengelola pendidikan di sekolah secara keseluruhan dan kepala madrasah adalah pemimpin formal pendidikan di sekolah. (Effendi, 1992)

Menurut (E. Mulyasa, 2003) di antara tugas da fungsi kepala madrasah adalah sebagai berikut: (1) kepala madrasah selaku edukator bertugas melaksanakan proses, pembelajaran secara efektif dan efisien, (2) kepala madrasah selaku manajer mempunyai tugas menyusun perencanaan, mengorganisasi kegiatan, mengarahkan kegiatan, mengoordinasikan kegiatan, melaksanakan pengawasan, melakukan evaluasi terhadap kegiatan, menentukan kebijaksanaan, mengadakan rapat, mengambil keputusan, mengatur proses belajar mengajar (PBM), mengatur administrasi ketatausahaan, kesiswaan, ketenagaan dan keuangan, mengatur organisasi intra sekolah dan mengatur hubungan madrasah dengan masyarakat dan instansi terikat, (3) kepala madrasah selaku administrator bertugas menyelenggarakan administrasi, antara lain: perencanaan, pengorganisasian, pengarahan, pengoordinasian, pengawasan, kurikulum, kesiswaan, ketatausahaan, ketenagaan, kantor, keuangan, perpustakaan, laboratorium, ruang keterampilan/kesenian, bimbingan konseling, UKS, OSIS, (4) kepala madrasah selaku supervisor bertugas menyelenggarakan supervisi mengenai proses belajar mengajar, antara lain: kegiatan bimbingan dan konseling, kegiatan ekstrakurikuler, kegiatan ketatausahaan, kegiatan kerja sama dengan masyarakat dan instansi terkait, saran prasarana, kegiatan OSIS dan kegiatan $6 \mathrm{~K}$ (keamanan, kebersihan, keindahan, ketertiban, kekeluargaan dan kerindangan), (5) kepala madrasah selaku leader bertugas memimpin dan memberikan teladan kepada guru, karyawan dan siswa, (6) kepala madrasah selaku inovator bertugas melakukan inovasi untuk kemajuan, perkembangan dan peningkatan mutu pendidikan, (7) kepala madrasah selaku motivator bertugas memberikan dorongan kepada guru, karyawan dan siswa, (8) kepala madrasah selaku konduktor budaya Islam bertugas menyelenggarakan kegiatan pembelajaran agar tumbuh dan berkembang kondisi yang Islam di lingkungan madrasah.

\section{KNERI AGURU}

Kinerja guru adalah gabungan dari 3 faktor yang terdiri dari (a) pengetahuan, khususnya pekerjaan yang menjadi tanggung jawab dalam bekerja faktor ini mencakup jenis dan jenjang pendidikan serta pelatihan yang pernah diikuti di bidangnya, (b) pengalaman, yang tidak sekedar berarti jumlah waktu lamanya dalam bekerja tapi berkenaan juga dengan substansi yang dikerjakan yang jika dilaksanakan dalam waktu yang cukup lama akan meningkatkan kemampuan dalam mengerjakan suatu bidang tertentu, (c) kepribadian, berupa kondisi di dalam diri seseorang dalam menghadapi bidang kerjanya seperti minat, bakat, kemampuan bekerja sama, keterbukaan, ketekunan, kejujuran dan sikap terhadap pekerjaan (Karen 2000). 


\section{METODOLOG PENELTAN}

Penelitian ini menggunakan pendekatan kualitatif ini dipilih untuk digunakan dalam penelitian dengan bermaksud untuk memahami perilaku manusia dari kerangka acuan si pelaku sendiri yakni bagaimana si pelaku memandang dan menafsirkan dari segi pendiriannya yang biasa disebut dengan persepsi emik begitu juga agar dapat mengetahui dan mendeskripsikan secara jelas dan rinci tentang manajemen kepala madrasah dalam meningkatkan kinerja guru di Madrasah Tarbiyah Islamiyah (MTS ) Jaho.

Dalam penelitian ini memakai perspektif fenomenologi yaitu peneliti memahami dan menghayati perilaku atau kegiatan para pemimpin dalam rangka mengembangkan kompetensi profesional guru di Madrasah Tarbiyah Islamiyah (MTS) Jaho. Untuk memahami, menghayati, realitas empiris tersebut, maka peneliti mengimplementasikan, membandingkan hasil terdahulu dan referensi sebagai bahan rujukan untuk memahami dan mengimplementasikannya.

Dalam penelitian ini pengumpulan data penulis kumpulkan menggunakan teknik pengumpulan data melalui observasi, wawancara (interview) dan dokumentasi.

\section{Teknik pengujian keabsahan data (validitas dan Reliabilitas data)}

Sebelum data yang telah di kumpulkan di analisis, maka data tersebut harus di uji keabsahannya, untuk menguji keabsahan data penelitian ini, menggunakan tringulasi dan perpanjangan pengamatan (tuntas dan jenuh). Peneliti akan melakukan cross check terhadap data yang telah diperoleh, dari wawancara dengan sumber 1, sumber 2, dan sumber 3. Dalam hal ini, data wawancara yang diperoleh dari kepala madrasah dan guru.

Kemudian, peneliti akan terus melakukan pengamatan yang lebih mendalam sampai akhirnya menjadikan data yang telah diperoleh menjadi data yang benar-benar valid.

Tringluasi adalah teknik pemeriksaan keabsahan data yang memanfaatkan sesuatu yang lain di luar data itu untuk keperluan pengecekan atau sebagai perbandingan terhadap data itu. Ada tiga macam tringulasi, yaitu:

a. Tringulasi sumber

Tringulasi sumber adalah langkah pengecekan kembali data-data yang diperoleh dari informan dengan cara menanyakan kebenaran data atau informasi kepada informan yang satu dengan informan yang lainnya antara kepala madrasah (termasuk wakil kepala bidang kurikulum, kesiswaan, dan sarana prasarana), guru (guru pns dan guru) itu sendiri.

b. Tringulasi metode

Tringulasi metode dilakukan dengan cara membandingkan informasi atau data dengan cara yang berbeda. Peneliti menggunakan tringulasi metode dengan wawancara, observasi, dan studi dokumentasi.

c. Tringulasi waktu

Tringulasi waktu adalah tahapan dalam melakukan penelitian, yaitu observasi awal yang masih bersifat umum (Grand Tour), kemudian melakukan observasi terfokus (Mini Tour), dan perpanjangan pengamatan (Depp observation). 


\section{Teknik Analisis Data}

Analisis data adalah penyusunan, pengaturan dan pengilahan data agar data dapat digunakan untuk dikategorikan dan didefinisikan atau dimaknai. Sesuai dengan data yang diperoleh dalam subjek peneliti Madrasah Tarbiyah Islamiyah (MTI) Jaho, maka penelitian ini menggunakan teknis analisis data kualitatif deskriptif dan analisis reflektif, yaitu analisis yang berpedoman pada cara berpikir yang merupakan kombinasi yang jitu antara berpikir induksi dengan deduksi. Analisis data ini untuk menjawab pertanyaan yang dirumuskan dalam penelitian, yaitu mengapa, alasan apa dan bagaimana. Dalam menganalisis data deskriptif kualitatif terdiri dari tiga kegiatan yaitu:

1. Pengumpulan data sekaligus reduksi data

2. Penyajian data

3. Penarikan kesimpulan

Terhadap analisis data, dalam penelitian ini dibagi menjadi yaitu pertama, tahap pendahuluan atau pengolahan data / kelengkapan data yang diperoleh, keterbatasan tulisan, kejelasan makna dan kesesuaian data yang lain. Kedua, tahap keorganisasian data yang merupakan inti dari analisis data. Ketiga, tahap penemuan hasil-hasil penelitian di cek kembali dalam rangka mendapatkan keabsahan dan kredibilitas data yang diperoleh peneliti dengan demikian hasil pembahasan penelitian ini didapat hasil yang akurat, menemukan halhal yang baru supaya dapat berkembang.

Pada tahap ini membutuhkan ketekunan observasi dan wawancara untuk mendapatkan data tentang berbagai hal yang dibutuhkan dalam peneliti, pengecekan keabsahan data menggunakan tringulasi data. Perbaikan data yang terkait dengan bahasa, penulisan maupun penyederhanaan data dan agar peneliti. Ini komunikatif dan dapat dipertanggung jawabkan, maka perlu diadakan konsultasi dengan dosen pembimbing untuk memperoleh masukan demi kesempurnaan laporan. Penaikan kesimpulan, sebagai analisis data dengan analisis model interaktif sebagaimana yang dikembangkan oleh miles dan buberman dalam Sugiyono yaitu alur kegiatan yang dilakukan adalah reduksi data, penyajian data dan verifikasi/ penarikan kesimpulan proses tersebut dapat digambarkan sebagai berikut:

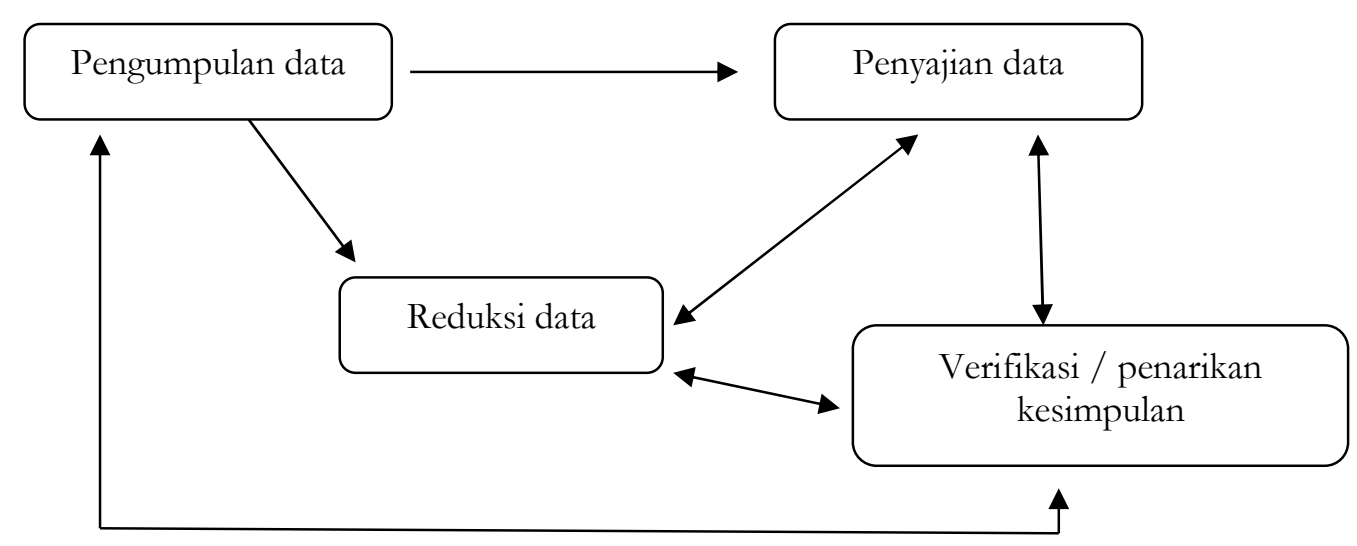

Gambar 1. Analisis data model interaktif 
Berdasarkan gambar tersebut terlihat bahwa, setelah peneliti melakukan pengumpulan data, maka peneliti melakukan antisipasi sebelum melakukan reduksi data. Reduksi data adalah merupakan analisis menajamkan, menggolongkan, mengarahkan, membuang data yang tidak relevan dan mengorganisasinya. Sehingga kesimpulan akhir dapat dirumuskan dan menyeleksi data secara ketat, membuat ringkasan dan rangkuman, merupakan kegiatan dari reduksi data. Dengan demikian reduksi data dapat berlangsung secara terus menerus selama penelitian berlangsung.

Data display (penyajian data) adalah untuk memaparkan data secara rinci dan sistematis setelah dianalisis ke dalam format yang disiapkan untuk itu. Namun data yang disajikan dalam bentuk data sementara untuk kepentingan peneliti dalam rangka pemeriksaan lebih lanjut sehingga diperoleh tingkat keabsahan. Jika ternyata data yang disajikan telah teruji kebenarannya maka akan bisa dilanjutkan pada tahap pemeriksaan kesimpulan-kesimpulan sementara. Akan tetapi jika data disajikan belum seusia maka konsekuensi belum bisa ditarik kesimpulan melainkan harus melakukan reduksi kembali.

Conclusion (penarikan kesimpulan) dilakukan dari awal pengumpulan data, penajian data, analisis data secara kualitatif dimulai dengan menentukan : apa artinya, mencatat keteraturan pola, bentuk-bentuk penjelasan konfigurasi yang memungkinkan aliran-aliran penyebab dan proporsional. Tiga tahap tersebut yang meliputi reduksi data, penyajian data, serta penarikan kesimpulan. Verifikasi antara satu dengan lainnya saling berkait, baik sebelum, selama maupun sesudah pengumpulan data yang disebut dengan analisis data. Penarikan kesimpulan, hal ini dimaksud untuk memberikan arti atau memakai data yang diperoleh baik melalui observasi, wawancara maupun dokumentasi.

Analisis data kualitatif dilakukan pada saat pengumpulan data dan setelah pengumpulan data. Dalam hal ini peneliti menggunakan metode analisis data deskriptif. Analisis deskriptif adalah usaha mendeskripsikan atau menggambarkan suatu gejala peristiwa, kejadian yang terjadi pada saat sekarang.

Dalam analisis data ini peneliti mendeskripsikan dan menguraikan tentang upaya kepala madrasah dalam meningkatkan kinerja guru di Madrasah Tarbiyah Islamiyah (MTI) Jaho. Dalam penelitian kualitatif ini analisis data dilakukan selam dan setelah pengumpulan data. Reduksi data dalam penelitian ini pada hakikatnya menyederhana dan disusun secara sistematis data tersebut. Hasil reduksi sebagiannya disajikan dalam bentuk display data, untuk menyajikan data digunakan uraian naratif, selanjutnya dibuat kesimpulan.

\section{HASIL PENEUTAN}

1. Upaya kepala madrasah untuk meningkatkan kinerja guru pada program perencanaan pembelajaran

Berbagai upaya yang dilakukan oleh kepala MTI agar guru mampu membuat perencanaan dengan baik yaitu sebagai berikut:

a. Diklat perencanaan pembelajaran

b. Pengawasan dan pemantauan

c. Melengkapi fasilitas yang dibutuhkan guru 
2. Upaya kepala madrasah untuk meningkatkan kinerja guru dalam pelaksanaan proses pembelajaran di madrasah Tarbiyah Islamiyah (MTI) Jaho

Dalam pelaksanaan proses pembelajaran di madrasah tarbiyah islamiyah (MTI) syekh djamil jaho. Upaya kepala sekolah dalam meningkatkan kinerja guru dalam proses belajar adalah salah satunya mengadakan supervisi kelas

Hasil pengamatan penulis bahwasanya pelaksanaan dari tugas kepala sekolah sebagai penanggung jawab semua kegiatan yang ada di sekolah perlu memantau pelaksanaan proses pembelajaran yang di lakukan guru di kelas. Beberapa upaya yang dilakukan kepala sekolah agar pelaksanaan proses pembelajaran yang dilakukan guru lebih baik. Kepala sekolah mengupayakan dengan mengikut sertakan guru dalam diklat dan MGMP pelaksanaan pembelajaran, pengawasan dan pemantauan dari kepala sekolah terhadap pelaksanaan kegiatan pembelajaran oleh guru.

Dalam proses pembelajaran, kepala madrasah melakukan berbagai upaya, di antarannya dalam membina loyalitas guru, dalam pembinaan loyalitas guru, kepala madrasah menempuh beberapa hal, di antaranya 1) dengan penilaian prestasi kerja, 2) dengan penetapan bagian kerja masingmasing, 3) dengan pemberian hasil kerja.

Dalam bidang pendayagunaan sumber belajar, kepala madrasah juga mengupayakan agar guru memanfaatkan pustaka untuk meminjamkan buku dan membaca bukubuku yang ada.

Dalam penggunaan media pembelajaran, kepala madrasah menganjurkan kepada guru untuk menggunakan media pembelajaran secara maksimal melalui ITC dan alat lainnya seperti buku paket. Hal ini di sampaikan kepala madrasah ketika diadakan rapat majelis guru yang di adakan setiap 15 hari serta kepala madrasah juga menyuruh kepada guru menggunakan metode pembelajaran yang bervariasi sesuai kebutuhan serta mencari bahan ajar dari buku dan melarang untuk menggunakan refensi dari sumber internet.

3. Upaya kepala madrasah untuk meningkatkan kinerja guru dalam evaluasi (penilaian) pembelajaran di Madrasah Tarbiyah Islamiyah (MTI) Jaho

Dalam melakukan evaluasi atau penilaian pembelajaran kepala madrasah dalam meningkatkan kinerja guru. Dilakukannya pembinaan dalam hal penyusunan program evaluasi, juga melakukan pembinaan dalam melakukan program evaluasi, juga melakukan pembinaan dalam melakukan program perbaikan dan pengayaan majelis guru, langkah-langkah antara lain dengan memotivasi guru menganalisis hasil evaluasi dan dengan memotivasi guru untuk membuat serta melaksanakan program perbaikan dan pengayaan di sekolah.

Selanjutnya juga kepala madrasah juga menyusun kriteria dan indikator keberhasilan pendidikan dan pembelajaran/bimbingan kepada sekolah. evaluasi hasil pembelajaran kami selaku kepala madrasah juga melakukan bimbingan kepada guru dalam menentukan aspek-aspek yang penting dalam di nilai dalam proses pembelajaran di tiap bidang pengembangan serta mengadakan penilaian kinerja guru dalam melaksanakan tugas pokok dan tanggung jawabnya.

Kepala Madrasah juga melakukan pengawasan kepada guru, dalam evaluasi hasil belajar, kepala madrasah sangat mem- 
butuhkan dibutuhkan sistem pengontrolan atau pengawasan yang dilakukan oleh pimpinan pada bagian-bagiannya, serta bagian-bagian pada rencana kerja yang telah dilaksanakannya. Sistem pengontrolan ini sangat bermanfaat sebagai evaluasi apakah pelaksanaan tugas sudah sesuai dengan rencana kerja pada tahun berikutnya dapat disusun.

\section{Upaya Kepala Madrasah untuk} meningkatkan kinerja guru dalam disiplin pembelajaran

Disiplin merupakan kunci utama yang harus ada pada setiap guru agar pelaksanaan pembelajaran dapat terlaksana dengan baik. Guru harus memiliki disiplin yang tinggi. Upaya kepala MTI Jaho dalam meningkatkan kedisiplinan yaitu dengan menyediakan presensi yang di cek setiap Minggu dan memberikan pembinaan bagi guru yang kurang disiplin. Hal tersebut diungkapkan oleh kepala sekolah yang menyatakan bahwa presensi di MTI Jaho masih secara manual, namun dalam presensi tersebut di cantumkan jam datang dan jam pulang masing-masing guru.

Hal tersebut dapat penulis lihat pada dokumen absen tersebut, tapi ada kekurangannya peneliti lihat guru tidak selalu rutin mengisi absen sehingga pegawai tata usaha sudah merekap kehadiran guru tersebut.

Dalam meningkatkan kinerja guru di bidang disiplin guru, kepala madrasah melakukan: 1) pembinaan, 2) pengawasan dan 3) tindakan dalam disiplin guru. hal ini dapat di gambarkan bahwa pengawasan telah membina disiplin guru melalui pengarahan secara tertulis dan tidak tertulis di samping juga mengadakan pengawasan melalui piket harian dan melakukan tindakan bagi yang melanggar.
Kemudian dilihat dari aspek evaluasi proses pembelajaran tergambar bahwa, di samping kepala madrasah melakukan pembinaan dalam hal penyusunan program evaluasi, juga melakukan pembinaan di lakukan dalam program perbaikan dan pengayaan kepada dewan guru, langkahlangkahnya antara lain dengan memotivasi guru untuk membuat serta melaksanakan program perbaikan dan pengayaan di sekolah.

Selanjutnya juga memberikan gambaran bahwa upaya peningkatan kinerja guru yang dilakukan kepala madrasah salah satunya juga dengan menerapkan kedisiplinan guru melalui, 1) pembinaan, 2) pengawasan, dan 3) tindakan dalam disiplin. Hal ini dapat di gambarkan bahwa pengawasan dalam membina disiplin guru melalui pengarahan serta tertulis dan tidak tertulis di samping juga mengadakan pengawasan melalui piket harian dan melakukan tindakan bagi yang melanggarny

\section{PENUTUP}

\section{Kesimpulan}

Program yang dilakukan kepala madrasah dalam meningkatkan kinerja guru pada Madrasah Tarbiyah Islamiyah (MTI) Syekh Muhammad Djamil Jaho telah disusun, meliputi program kerja tahunan dan semester serta program supervisi. Program peningkatan kinerja guru dilaksanakan untuk mengadakan pembinaan, membimbing dan mengarahkan guru supaya lebih berkualitas, sehingga dapat dirincikan sebagai berikut:

1. Upaya untuk meningkatkan kinerja guru dalam bidang perencanaan pembelajaran dengan melakukan pembinaan tanggung jawab kepada guru 
terhadap tugas yang telah dibebankan kegiatan MGMP dan juga melengkapi sarana untuk membuat perencanaan pembelajaran seperti penyediaan buku serta kepala madrasah memeriksa perangkat guru seperti RPP.

2. Upaya kepala madrasah untuk meningkatkan kinerja guru dalam bidang pelaksanaan pembelajaran, kepala madrasah meningkatkan sistem pengelolaan kelas dengan melakukan supervisi dan pengawasan serta melihat guru mengajar kemudian melengkapi sarana pembelajaran seperti buku pelajaran kemudian lagi melihat guru dalam penggunaan media pembelajaran serta metode pembelajaran.

3. Upaya kepala madrasah untuk meningkatkan kinerja guru dalam bidang evaluasi pembelajaran, kepala madrasah telah melakukan beberapa upaya seperti memeriksa buku evaluasi hasil pembelajaran guru dalam bentuk hasil ulangan harian, analisis ulangan harian serta program perbaikan dan pengayaan.

4. Upaya kepala madrasah untuk meningkatkan kinerja guru dalam bidang disiplin guru, kepala madrasah melakukan upaya dengan mengumpulkan perangkat pembelajaran guru, serta menyediakan daftar presensi.

\section{Saran}

Berdasarkan kesimpulan di atas, dapat disampaikan beberapa saran di antaranya sebagai berikut:

1. Bagi guru, diharapkan dapat meningkatkan kinerjanya secara optimal baik dalam perencanaan pembelajaran, pelaksanaan, evaluasi serta meningkatkan disiplin pembelajaran

2. Bagi kepala madrasah, diharapkan dapat mempertahankan kegiatan supervisi ini dengan melakukan secara terus menerus agar menciptakan pembelajaran yang optimal

3. Bagi ketua yayasan beserta jajarannya, diharapkan untuk melengkapi sarana dan prasarana untuk terlaksananya proses pembelajaran

4. Agar hasil penelitian ini dapat menjadi bahan pertimbangan bagi pengelola atau pengurus madrasah untuk arah yang lebih baik.

\section{KEPUSTAKAANACUAN}

Anoraga Pandji, 2007. Psikologi Kerja, Jakarta: Rineka Cipta.

Ek. Muchatar Effendy, 1990. Manajemen Suatu Pendekatan Berdasarkan Ajaran Islam, Jakarta: Gramedia.

E.Mulyasa. 2003. Menjadi Kepala sekolah Profesional, Jurnal ilmiah Kesehatan Bandung, Remaja Rosda Karya.

Gauzali, 2000. Manajemen Sumber Daya Manusia. Jakarta, Djambatan.

Suharsimi Arikunto, 1993. Metode Penelitian Suatu Pendekatan Praktek, Jakarta, rineka Cipta.

Halim Hanafi, 2011. Metode Penelitian Kependidikan untuk Penelitian Skripsi, Tesis dan Disertasi, Batusangkar Press.

Moleong J Lexy, 2007. Metodologi Penelitian Kualitatif edisi revisi, Bandung; Rosda Karya.

Karen R Seeker dan Joe B Wilson, 2000. Menyusun Rencana Kerja Karyawan. Bandung. PT Binaan Presindo.

Yurman M Nur, 2008. Kontribusi Kepemimpinan Kepala Sekolah dan Komitmen guru Terbadap Kinerja Guru $S D$, PPS UNP. 